\title{
Construction Simulation Analysis of 60m-span Concrete Filled Steel Tube arch bridge
}

\author{
Jing Xian SHI*, Qing Hua DING \\ Oxbridge College, Kunming University of Science and Technology, KunMing 650106Yunnan, China
}

\begin{abstract}
The construction process of the CFST arch bridge is complicated. The construction process not only affects the structural stress in the installation, but also determines the form a bridge and internal force of the bridge. In this paper, a $60 \mathrm{~m}$ span concrete filled steel tube tied arch bridge is taken as the background, and a three-dimensional finite element simulation model is established by using the MIDAS/Civil bridge structure analysis software. The elevation of the main arch ring, the beam stress, the forces in hanger rods and the modal frequency of the main arch during the construction stage are calculated, and the construction process is simulated and analyzed. Effectively and reasonably guide the construction and ensure that the line and force conditions of the completed bridge meet the design requirements and provides a reliable technical guarantee for the safe construction of the bridge.
\end{abstract}

\section{Introduction}

The engineering background of this paper is a simply supported concrete-filled steel tube tied arch bridge, which is located on the new urban road of Suijiang County in Yunnan, China. It is part of the relocation project of Xiangjiaba Hydropower Station. The layout of the main bridge is shown in Figure 1. The theoretical calculation of the bridge has a $60 \mathrm{~m}$ span, a calculated calculated rise of arch is $12 \mathrm{M}$, and ratio of rise to span is $1 / 5$. The bridge deck structure adopts the vertical and horizontal beam system and integral bridge deck. There are 2 concrete-filled concrete arches in the entire bridge, and the cross section of the arch rib is dumbbell type. The design speed of $20 \mathrm{~km} / \mathrm{h}$, bridge deck width: $0.25 \mathrm{~m}$ (railing) $+1.75 \mathrm{~m} \quad$ (pavement) $+8.0 \mathrm{~m} \quad$ (roadway) $+1.75 \mathrm{~m}$ (pavement) $+0.25 \mathrm{~m}$ (railing), The basic intensity is 7 degrees, the peak acceleration of earthquake motion is $0.112 \mathrm{~g}$, and the category of anti-seismic is the C class.

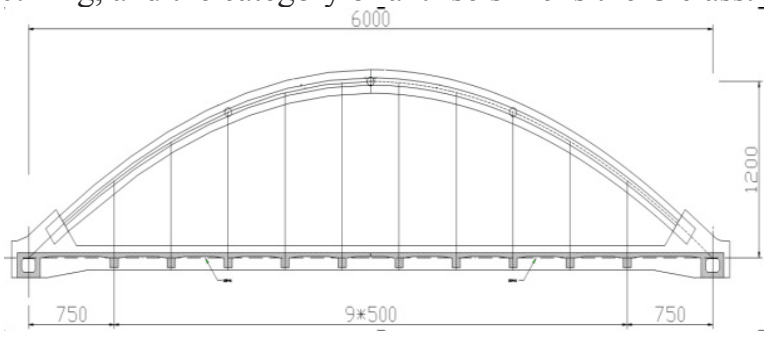

Fig. 1. The layout of the main bridge/Unit: $\mathrm{cm}$

Concrete filled in bridge deck and steel tube arch rib is C50 micro-expansive concrete, the crossbeam of tie beam with C50 concrete; all ordinary steel bars are HRB400. The hanger rod adopts the OVM.GJ15-12 Steel Strand Full-bundle-extruding cable system, the standard strength is $\mathrm{fpk}=1860 \mathrm{MPa}$, breaking force is
$3125 \mathrm{kN}$, the outer color HDPE sheath of the hanger rod is recommended to use orange.

\section{The brief description of the analysis model}

The simulation analysis of construction uses the MIDAS/Civil bridge structure analysis program. The structural analysis model is shown in Figure 2. The bridge has 516 units and 1324 nodes, in which the main arch, the wind bracing, the tie beam, the end floor beam and the inner beam unit unit are the space beam units. The hanger rod adopts the space truss element, and the bridge panel is analyzed by the space plate element. The boundary conditions in the analysis are as follows: the hinges of the full framing bottom(only compression, stiffness is $100 \mathrm{kN} / \mathrm{mm}$ ), the arch springing is hinged at both ends(longitudinal is movable), and the cast-in-place bridge deck unit is consolidated with the tie beam and cross beam.

There are 10 main kinds of calculation section types of the unit (variable cross-section is automatically calculated by the program), in which the concrete filled steel tube is used in the joint section of the construction stage, and there are 3 types of material types. The specific parameters are shown in table 1 and table 2 . In the material parameters, the self weight and the constant load of the main arch are determined by the relation between the actual bulk density and the sectional area.

\footnotetext{
*Corresponding author: sara_shivip@163.com
} 


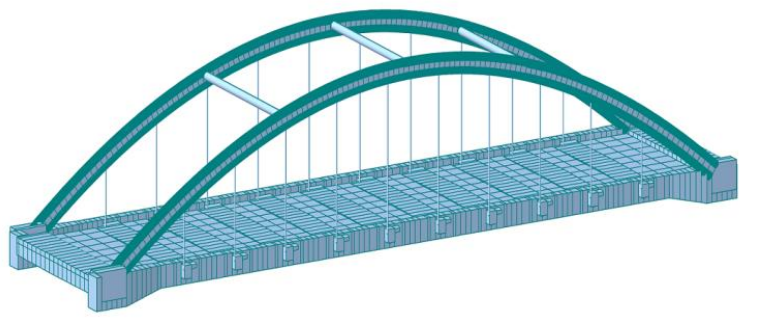

Fig.2. Simplified calculation model of the whole structure

Table 1. Cross section parameter summary of calculation model

\begin{tabular}{ccccc}
\hline $\begin{array}{c}\text { No of } \\
\text { Cross } \\
\text { sectio } \\
\mathrm{n}\end{array}$ & Location & $\begin{array}{c}\text { Cross } \\
\text { section } \\
\text { area } \\
\mathrm{m}^{2}\end{array}$ & Izz & Czm \\
\hline 1 & Boom & 0.0059 & 0 & 0.0435 \\
2 & Tie beam1 & 3.5 & 0.5717 & 1.25 \\
3 & Tie beam2 & 1.36 & 0.0725 & 0.85 \\
4 & $\begin{array}{c}\text { Variable cross-section } \\
\text { of tie beam }\end{array}$ & 3.5 & 0.5717 & 1.25 \\
5 & End floor beam & 6.38 & 4.4713 & 1.1 \\
6 & $\begin{array}{c}\text { Variable cross-section } \\
\text { of end floor beam }\end{array}$ & 2.3871 & 1.3599 & 0.7565 \\
7 & Inner cross beam & 0.7 & 0.0286 & 0.5 \\
8 & Arch--steel tube & 0.069 & 0.0035 & 0.8 \\
9 & Arch-concrete & 0.7569 & 0.0172 & 0.7848 \\
10 & Wind bracing & 0.3318 & 0.0088 & 0.325 \\
\hline
\end{tabular}

Notes: Izz-The moment of inertia to the $\mathrm{Z}$ axis of the unit local coordinate system(Moment of Inertia) $\left(\mathrm{m}^{4}\right)$; $\mathbf{C z m}$-In the direction of the $-\mathrm{z}$ axis along the local coordinate system of the unit, the distance between the unit section and the shaft to the edge fiber(m).

Table 2. Material parameter summary of calculation model

\begin{tabular}{|c|c|c|c|c|c|}
\hline $\begin{array}{l}\mathrm{N} \\
\mathrm{o} .\end{array}$ & Unit type & $\begin{array}{l}\text { Material } \\
\text { type }\end{array}$ & $\begin{array}{c}\text { Elasticit } \\
\text { y } \\
\text { modulus } \\
(\mathrm{MPa})\end{array}$ & $\begin{array}{c}\text { unit } \\
\text { weight } \\
\left(\mathrm{kN} / \mathrm{m}^{3}\right)\end{array}$ & $\begin{array}{c}\text { thermal } \\
\text { coefficie } \\
\text { nt of } \\
\text { expansio } \\
\mathrm{n} 1 /{ }^{\circ} \mathrm{C}\end{array}$ \\
\hline 1 & $\begin{array}{c}\text { Concrete in } \\
\text { plate and } \\
\text { steel tube } \\
\text { arch }\end{array}$ & $\begin{array}{c}\text { Concret } \\
\mathrm{e}\end{array}$ & $3.45 \mathrm{e} 4$ & 25 & $1.0 \mathrm{e}-5$ \\
\hline
\end{tabular}

\begin{tabular}{|c|c|c|c|c|c|}
\hline 2 & $\begin{array}{l}\text { arch rib } \\
\text { and wind } \\
\text { bracing }\end{array}$ & $\begin{array}{c}\text { rolled } \\
\text { steel }\end{array}$ & $2.10 \mathrm{e} 5$ & 78.5 & $1.2 \mathrm{e} 5$ \\
\hline 3 & $\begin{array}{l}\text { prestressin } \\
\text { g force } \\
\text { boom }\end{array}$ & $\begin{array}{c}\text { rolled } \\
\text { steel }\end{array}$ & $1.95 \mathrm{e} 5$ & 78.5 & $1.2 \mathrm{e}-5$ \\
\hline
\end{tabular}

\section{Construction simulation analysis}

\subsection{Division of construction stage}

The concrete filled steel tubular arch section is constructed by bracket method. The arch ribs, tie beam, beams and deck plates are cast-in-place on the support formwork, and the steel structures such as arch ribs, wind bracing and so on are all fabricated in factories and assembled on site. Each arch rib is divided into three sections and assembled on the spot. According to the design drawing and construction management plan, the whole bridge construction is divided into 30 calculation stages to simulate, the total time period is 236 days, and table 3 is detailed.

\subsection{Load calculation}

The unit weight of empty steel pipe and hanger; each section of the concrete; tie beam and crossbeam are $78.5 \mathrm{kN} / \mathrm{m}^{3} ; 25 \mathrm{kN} / \mathrm{m}^{3} ; 26 \mathrm{kN} / \mathrm{m}^{3}$, respectively. The self weight is assigned to each node in the form of the equivalent concentrated load. The shrinkage and creep are calculated at 3000 days after the bridge is formed. The temperature load is considered at heating-up $20^{\circ} \mathrm{C}$ and cooling $20^{\circ} \mathrm{C}$ uniformly. The hangers and arch ribs are considered in accordance with the individual temperature difference of $\pm 10^{\circ} \mathrm{C}$. This structure is an external static structure so that the settlement of the support is not considered. Vehicle live load is bidirectional 2 lanes, secondary road, the impact coefficient is automatically calculated by program. Crowd load is $3.5 \mathrm{KN} / \mathrm{M}$, width of the sidewalk is $1.75 \mathrm{~m}$. The second constant load is applied to the bridge deck with uniform load, considering the constant load of bridge deck pavement, edge stone, railing and sidewalk. $\mathrm{q}=(1051.848+0.3767+48.3633+2119.53) \mathrm{kN} / 404.46$ $\mathrm{m}^{2}=7.69 \mathrm{kN} / \mathrm{m}^{2}$

Table 3. Division of bridge construction stage

\begin{tabular}{|c|c|c|c|c|c|}
\hline $\begin{array}{l}\text { construction } \\
\text { stage }\end{array}$ & Duration & start time & $\begin{array}{l}\text { terminal } \\
\text { time }\end{array}$ & $\begin{array}{l}\text { Name of construction } \\
\text { component }\end{array}$ & Working condition description \\
\hline 1 & 30 & 1 & 31 & Tie beam & Cast-in-place beam \\
\hline 2 & 30 & 31 & 61 & $\begin{array}{l}\text { End crossbeam, Inner } \\
\text { crossbeam }\end{array}$ & Cast-in-place end crossbeam and inner beam \\
\hline $3-7$ & 1 & 61 & 64 & End crossbeam & Tension prestressed steel bar N1-N3 - N2 - N4 \\
\hline
\end{tabular}




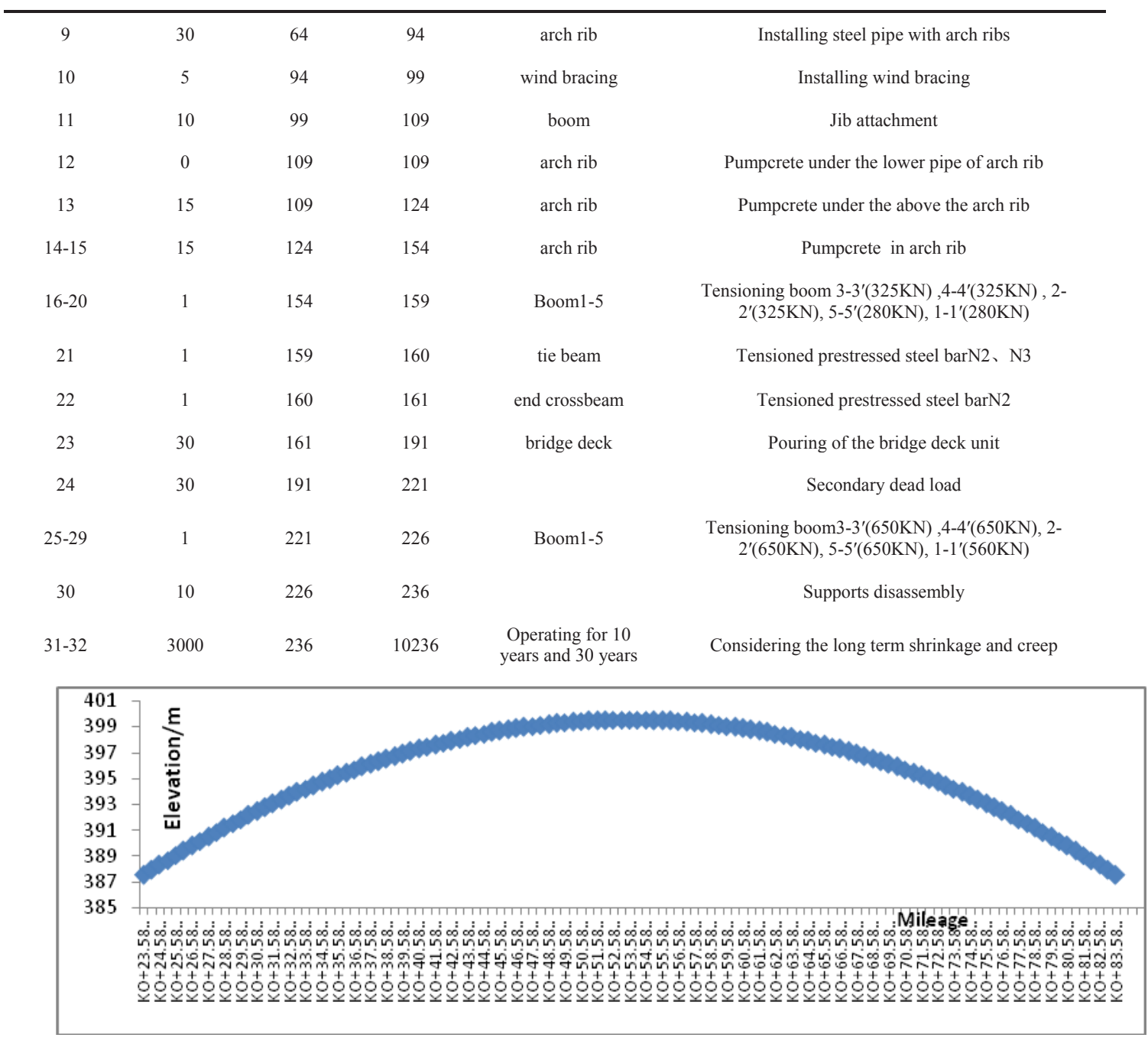

Fig.3. Arch ring linear of bridge

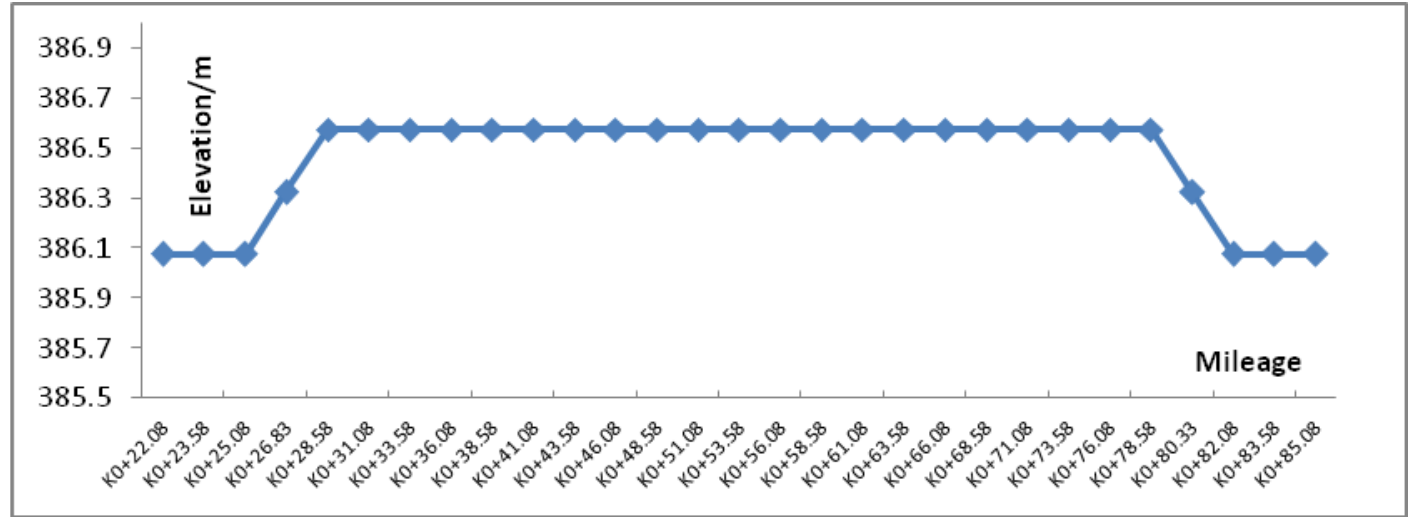

Fig. 4. Tie beam linear of bridge

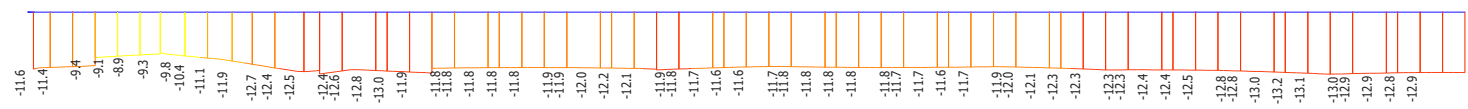

A Compression stress envelope of the upper edge of a tie beam(half bridge)

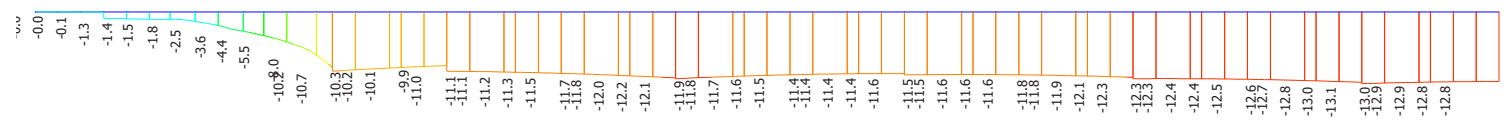


B Compression stress envelope of the lower edge of a tie beam(half bridge)

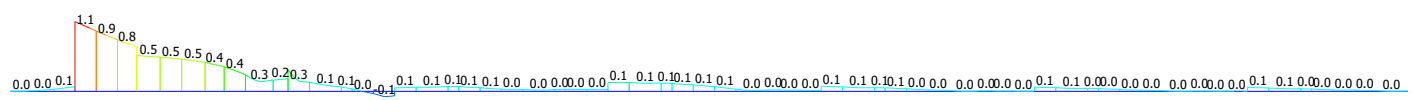

C The tensile stress envelope of the upper edge of a tie beam(half bridge)

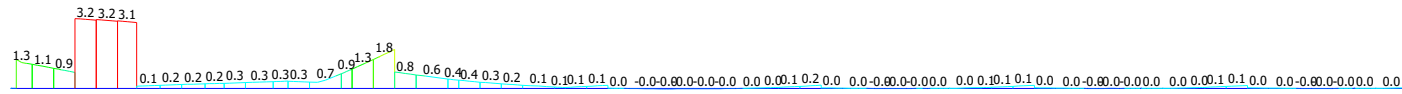

D The tensile stress envelope of the lower edge of a tie beam(half bridge)

Fig.5. Calculation result of tie beam stress

\section{Main results of construction phase calculation}

\subsection{The elevation of arch ring and tie beam}

Calculation of the design elevation of the tie beam and arch based on the design drawings. According to the calculation results of the monitored calculation model and the formula of the specification, the pre arch degree and the bridge line form are calculated, the long term deflection is positive after calculation. The anti pre arch is not required according to the specification, so the design elevation of the girders and arches is shown in figures 3 and 4 . The accumulative displacement of each node in the finished bridge is downward $3 \mathrm{~mm}$, the tie beam is upward $5 \mathrm{~mm}$ and the crossbeam is upward $12 \mathrm{~mm}$. Therefore, it is not necessary to set up the pre arch of the construction, and the elevation of the model is the sum of the design elevation and the deformation of the support.
According to the monitoring and analysis results, the stress envelope diagram of tie beams in all stages of the construction process is shown in Figure 5, the maximum compressive stress is $13.2 \mathrm{MPa}$, and the maximum tensile stress is $1.8 \mathrm{MPa}$ (In the upper edge drawing, the 2.7 MPa-6.2MPa near the support is due to the failure of the whole modeling to consider the local force, not the real stress of the structure. ), which meets the specification requirements.

\subsection{Checking calculation of cable force of boom}

According to the calculation results, the maximum cable force at each stage of the boom in the whole construction process is shown in Table 4 . It can be seen from the table that the safety factor is more than 4.0 , which meets the requirements of the safety factor of the cable in the construction state of the specification $<$ Guidelines for Design of Highway Cable-stayed Bridge $>$ (JTG/T D65-12007)3.4.2.

\subsection{Checking calculation of tie beam stress}

Table 4. Calculation result of cable force of boom

\begin{tabular}{|c|c|c|c|c|c|}
\hline $\begin{array}{c}\text { Boom } \\
\text { No. }\end{array}$ & $\begin{array}{l}\text { Boom } \\
\text { quantity }\end{array}$ & $\begin{array}{c}\text { sectional } \\
\operatorname{area}\left(\mathrm{mm}^{2}\right)\end{array}$ & $\begin{array}{l}\text { cable force } \\
\text { of the end } \\
\text { beam }(\mathrm{KN})\end{array}$ & $\begin{array}{l}\text { Cable force } \\
\text { at the arch } \\
\text { end }(K N)\end{array}$ & $\begin{array}{l}\text { safety } \\
\text { factor }\end{array}$ \\
\hline $\begin{array}{l}101 \\
102\end{array}$ & 4 & 1680 & 572.2 & 572.4 & 5.46 \\
\hline $\begin{array}{l}201 \\
202\end{array}$ & 4 & 1680 & 661 & 661.3 & 4.73 \\
\hline $\begin{array}{l}301 \\
302\end{array}$ & 4 & 1680 & 649.8 & 650.2 & 4.81 \\
\hline $\begin{array}{l}401 \\
402\end{array}$ & 4 & 1680 & 650.8 & 651.2 & 4.80 \\
\hline $\begin{array}{l}501 \\
502\end{array}$ & 4 & 1680 & 666.3 & 666.7 & 4.69 \\
\hline
\end{tabular}

\subsection{Frequency and mode of vibration}

The results of the frequencies and modes of each stage are shown in Figure 6.

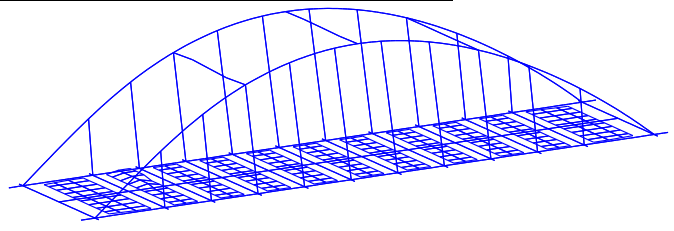


A First stage of mode of vibration( $(\mathrm{f}=0.689 \mathrm{HZ})$

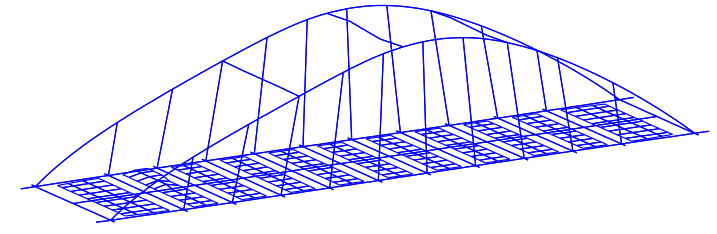

B Second stage of mode of vibration( $f=1.774 \mathrm{HZ})$

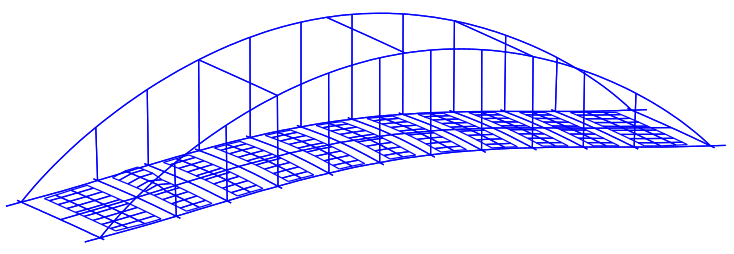

C Third stage of mode of vibration( $(\mathrm{f}=2.156 \mathrm{HZ})$

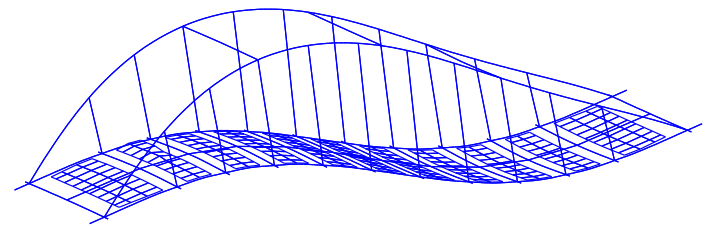

D Forth stage of mode of vibration $(\mathrm{f}=2.712 \mathrm{HZ})$

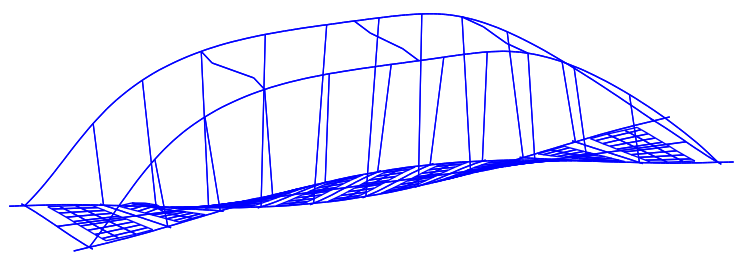

E Fifth stage of mode of vibration $(\mathrm{f}=3.424 \mathrm{HZ})$

Fig.6. The frequencies and modes of each stage

\section{Main results of construction phase calculation}

This paper combines the example of the construction monitoring of the steel tube concrete tied arch bridge with $60 \mathrm{~m}$. The selection of load calculation parameters, the division of construction stages, the calculation of the vertical formwork elevation of the arch ring and the girder are mainly elaborated, and a reasonable bridge line is determined. The stress of the tie beam and the cable force of the boom, as well as the frequency and mode of the bridge are calculated.

According to the simulation calculation of the construction, the data of the height and stress of the structure are obtained, so that the construction of the bridge is carried out in order. In order to ensure the reasonable theoretical basis of the bridge alignment and stress, it provides a reliable technical guarantee for the safe construction of the bridge.

\section{Acknowledgements}

Project Source: Yunnan Provincial Department of Education(2017ZZX319);

\section{References}

1. People's Republic of China Ministry of Transportation. JTGD60-2015General Code for Design of Highway Bridges and Culverts Beijing: People's Communications Press.2015

2. People's Republic of China Ministry of Transportation. JTGD62-2004 Code for Design of Highway reinforced concrete and prestressed concrete and Culverts. Beijing: People's Communications Press.2004.

3. People's Republic of China Ministry of Transportation. JTG/T D65-1-2007Design Specifications of Highway Cable-stayed Bridge. Beijing: People's Communications Press.2004.

4. Midas IT (Beijing)Corporation.MIDAS/CIVIL Analys for Civil strueture2006.

5. ZHAO Hui,HAO Chao, Analysis of Mechanical Performance of Tied Arch Bridge with Multiple Arch Ribs [J]. World Bridge2013(41)52-56.

6. Wang Zhijun,Li Nianwei. Construction Monitoring for Concrete-filled Steel Tube Rigid Tied Bar Arch Bridge [J] . CONSTRUCTION TECHNOLOGY 2010(10) 63-66. 